\title{
TERAPI KELOMPOK TERAPEUTIK DALAM MENINGKATKAN KEMAMPUAN IBU, BAYI DAN RASA PERCAYA BAYI
}

\author{
Yuniar Mansye Soeli*, Budi Anna Keliat, Titin Ungsianik \\ Fakultas Ilmu Keperawatan Universitas Indonesia, Depok 16424, Indonesia \\ *E-mail: ners.yuniar@gmail.com
}

\begin{abstract}
Abstrak
Stimulasi bayi adalah kegiatan merangsang kemampuan dasar bayi yang diberikan dari lingkungan luar hidup bayi. Kegiatan stimulasi yang dilakukan secara rutin dapat meningkatkan kemampuan bayi. Tujuan penelitian ini mengidentifikasi pengaruh terapi kelompok terapeutik terhadap kemampuan ibu, kemampuan bayi dan rasa percaya bayi. Desain penelitian yang digunakan adalah quasi eksperimen pre post test with control group. Responden dalam penelitian ini dipilih secara purposive sampling. Sampel dalam penelitian ini adalah ibu yang memiliki bayi usia 6-12 bulan sebanyak 80 ibu dan bayinya. Hasil penelitian menunjukkan terapi kelompok terapeutik meningkatkan kemampuan ibu, kemampuan bayi dan rasa percaya bayi secara bermakna $(p<0,05)$ serta lebih tinggi secara bermakna dibanding ibu yang tidak mendapatkan terapi kelompok terapeutik.Terapi kelompok terapeutik direkomendasikan untuk dilakukan pada tatanan pelayanan kesehatan di masyarakat sebagai bentuk pelayanan kesehatan jiwa bagi ibu yang mempunyai bayi.
\end{abstract}

Kata kunci: kemampuan ibu menstimulasi, kemampuan perkembangan, rasa percaya bayi, terapi kelompok terapeutik

\begin{abstract}
Therapy of Therapeutic Group in Improving Mothers' Ability, Baby and Babies' Confidence. Stimulation is an activity to stimulate baby's basic ability that is given from the outside environment. Stimulation activity which is carried out repeatedly can enhance babies' ability. The purpose of this study identifies therapy effect of therapeutic group toward mothers' ability, the babies' ability and babies' confidence. The research design is quasi-experimental that is used preposttest with a control group. In this study, respondents were selected by purposive sampling. Moreover, the sample of this study was 80 mothers who had babies on 6 to 12 months. The results showed that therapy of therapeutic group increased mothers' ability in stimulating babies developmental significantly ( $p>0.05)$. Furthermore, the therapy for therapeutic group also was increasing the babies developmental significantly ( $p>0.05)$, and enhanced the babies' confidence significantly $(p>0.05)$. The result of this study, mothers who received therapeutic therapy had significantly result higher than mothers who did not receive therapeutic therapy. Therapeutic group therapy is recommended to be used in the health service framework on the community as a form of mental health services for mothers who have had a baby.
\end{abstract}

Keywords: mothers' ability to stimulate, ability developmental, babies' confidence, therapy of therapeutic group

\section{Pendahuluan}

Masalah kekerasan pada anak telah menjadi perhatian dunia. Kekerasan terhadap anak terus terjadi sepanjang kehidupan manusia. Komisi Perlindungan Anak Indonesia (KPAI) (2013) mengatakan tindak kekerasan terhadap anak adalah segala bentuk ucapan sikap dan tindakan yang dapat menimbulkan kesakitan, gangguan psikis, penelantaran ekonomi, dan sosial ter- hadap anak oleh orang tua atau orang dewasa lainnya. Hasil penelitian Putri (2008) menunjukkan dua bentuk kekerasan terhadap anak dengan alasan memberi hukuman yang mendidik yaitu hukuman fisik, seperti dicubit, push up, lari keliling lapangan, dilempar dengan menggunakan alat tulis, dijemur, ditampar, dipukul, ditendang dan hukuman non fisik, seperti mencemooh dan mengancam. Kekerasan pada anak dapat terjadi secara fisik, psikis, ver- 
bal, maupun seksual dan insiden kejadian kekerasan semakin meningkat.

Perilaku kekerasan pada bayi dan anak sudah menjadi masalah kesehatan nasional dan menjadi prioritas intervensi saat insiden kejadian perilaku kekerasan mencapai lebih dari dua juta kejadian per tahun (Videbeck, 2008). WHO (2003) dalam global champaign for violence prevention menjelaskan bahwa sebanyak 1,6 juta penduduk dunia kehilangan hidup karena tindak kekerasan dan terjadi kematian karena tindak kekerasan pada anak di bawah usia 15 tahun). Di Indonesia, berdasarkan laporan akhir tahunan Komisi Perlindungan Anak Indonesia (2013) kekerasan terhadap anak sudah mencapai angka 3023 kasus dimana kekerasan fisik mencapai $31,06 \%$, kekerasan seksual $40,77 \%$ dan kekerasan psikis 28,18\%. Dari 3023 kasus perincian dari klasifikasi usia adalah 849 kasus (29\%) terjadi pada anak usia 0-5 tahun, 757 kasus (26\%) pada usia 6-12 tahun, dan 1291 kasus (45\%) pada usia 13-17 tahun (KPAI, 2013). Sedangkan, pada tahun 2015 meningkat secara signifikan sebesar 6006 kasus kekerasan pada anak. Melihat tingginya angka kekerasan pada perlu adanya upaya promotif dalam rangka untuk mencegah terjadinya kekerasan pada anak dan meningkatkan tumbuh kembang anak khususnya pada bayi. Upaya untuk meningkatkan tumbuh kembang anak adalah dengan merangsang kemampuan anak melalui stimulasi yang terarah.

Kemampuan dasar anak yang dirangsang dengan stimulasi terarah adalah kemampuan gerak kasar, kemampuan gerak halus, kemampuan kognitif, kemampuan bahasa, kemampuan emosi, kemampuan kepribadian, kemampuan moral, kemampuan spiritual, serta kemampuan psikososial. Melakukan stimulasi yang memadai artinya merangsang otak anak sehingga perkembangan kemampuan gerak, kognitif dan bahasa, emosi, kepribadian, moral, spiritual, dan psikososial pada anak berlangsung secara optimal sesuai dengan umur anak. Dengan stimulasi yang terarah dan teratur tumbuh kembang anak akan lebih cepat dan motivasi belajar akan timbul jika diberikan lingkungan yang kondusif, ganjaran atau hukuman yang wajar, kelompok sebaya, cinta dan kasih sayang serta kualitas interaksi anak-orang tua. (Soetjiningsih \& Ranuh, 2012).

Kegiatan stimulasi, deteksi dan intervensi dini penyimpangan tumbuh kembang yang menyeluruhdan terkoordinasi yang diselenggarakan dalam bentuk kemitraan antara keluarga (orang tua, pengasuh anak, dan anggota keluarga lainnya), masyarakat (kader, tokoh masyarakat, organisasi profesi, lembaga swadaya masyarakat, dan sebagainya) dengan tenaga profesional (kesehatan, pendidikan dan sosial), akan meningkatkan kualitas tumbuh kembang anak usia dini dan kesiapan memasuki jenjang pendidikan formal (Depkes, 2006). Maka sebagai orang tua hendaknya mampu memberikan stimulasi terhadap anak sesuai dengan kelompok perkembangannya di lingkungan keluarganya.

Upaya yang dapat dilakukan untuk meningkatkan kemampuan keluarga terhadap kebutuhan kesehatan perkembangan anggota keluarga khususnya orang tua yang memiliki bayi adalah dengan memberikan terapi yang bisa melibatkan partisipasi langsung dari orang tua terkait tumbuh kembang bayi yang dinamakan terapi kelompok terapeutik (TKT). Terapi kelompok terapeutik (TKT) merupakan salah satu jenis dari terapi kelompok yang memberi kesempatan kepada anggotanya untuk saling berbagi pengalaman, saling membantu satu dengan lainnya, untuk menemukan cara menyelesaikan masalah dan meningkatkan kemampuannya. (Townsend, 2009). Terapi kelompok terapeutik (TKT) telah memberikan peningkatan bagi perkembangan bayi. Hal ini dibuktikan dengan penelitian yang dilakukan Smith, Cumming, dan Xeros-Constantinides (2010) menunjukkan bahwa terdapat peningkatan perkembangan pada bayi dan peningkatan interaksi antara ibu dan bayi yang mendapat terapi kelompok. Penelitian ini juga didukung dengan penelitian yang dilakukan oleh Furniss, et al. (2013) menunjukkan peningkatan pengetahuan orang tua dan perkembangan psikososial anak. Penelitian 
lainnya juga dilakukan oleh Restiana, Keliat, Gayatri, dan Daulima (2010) membuktikan terapi kelompok terapeutik pada bayi dapat meningkatkan kemampuan ibu secara kognitif dan psikomotor serta rasa percaya bayi. Tetapi penelitian tentang pengaruh terapi kelompok terapeutik (TKT) terhadap kemampuan ibu, bayi yang terdiri dari delapan aspek perkembangan (motorik, kognitif, bahasa, emosi, kepribadian, moral, spiritual dan psikososial), dan rasa percaya bayi belum dilakukan.

Berdasarkan pemaparan tersebut maka peneliti meneliti tentang pengaruh terapi kelompok terapeutik (TKT) untuk melihat pengaruh terapi kelompok terapeutik terhadap kemampuan ibu, bayi, dan rasa percaya bayi.

\section{Metode}

Desain dalam penelitian ini menggunakan desain quasi-experiment one group pretest-posttest design with control group yang melihat pengaruh suatu intervensi, yaitu terapi kelompok terapeutik terhadap kemampuan ibu, bayi dan rasa percaya bayi. Populasi dalam penelitian ini adalah semua ibu yang memiliki bayi usia $0-18$ bulan. Metode sampling yang digunakan adalah purposive sampling dengan beberapa kriteria inklusi. Jadi jumlah sampel yang didapatkan sebanyak 80 responden yaitu ibu yang memiliki bayi berusia 6-12 bulan. Total seluruh waktu penelitian mulai dari penyusunan proposal hingga sidang sebanyak 25 minggu, yaitu mulai minggu pertama Desember 2015 sampai dengan minggu kedua Juni 2016. Instrumen yang digunakan terdiri dari karakteristik responden, kemampuan kognitif dan psikomotor ibu, kemampuan bayi dan rasa percaya bayi. Penelitian dilaksanakan di Kelurahan Oluhuta dan Kelurahan Dutohe. Penelitian ini telah mendapat persetujuan Komisi Etik Fakultas Ilmu Keperawatan Universitas Indonesia.

\section{Hasil}

Hasil penelitian ini dijabarkan tentang karakteristik responden, kemampuan ibu, bayi dan rasa percaya bayi sebelum dan sesudah terapi kelompok terapeutik, hubungan kemampuan ibu terhadap kemampuan bayi, hubungan kemampuan ibu terhadap rasa percaya bayi dan hubungan kemampuan bayi dengan rasa percaya bayi.

Karakteristik usia ibu berdasarkan usia, menunjukan nilai rata-rata sampel yakni berusia 28,94 tahun dengan usia termuda yakni 17 tahun dan usia tertua yakni 43 tahun. Berdasarkan distribusi pekerjaan, dapat dilihat bahwa sebanyak $60,0 \%$ ibu tidak bekerja, tingkat pendidikan ibu lebih banyak yang berpendidikan tinggi (55\%). Berdasar penghasilan keluarga, ibu didominasi oleh penghasilan di atas UMR Rp1.875.000 dan dari urutan anak menunjukkan proporsi terbesar adalah multipara yaitu 44 ibu (55\%). Sedangkan karakteristik bayi menunjukkan umur termuda yakni 6 bulan dan umur tertua yakni 11

Tabel 1. Perbedaan Peningkatan Kemampuan Kognitif Ibu Bayi antara yang Mendapatkan TKT dan tidak Mendapatkan TKT

\begin{tabular}{lcc}
\hline \multicolumn{1}{c}{ Pengukuran } & Mean (\%) & p \\
\hline Mendapatkan TKT & $36,17 \%$ & 0,000 \\
Tidak mendapatkan TKT & $-3,42 \%$ & $0,00 \%$ \\
\hline
\end{tabular}

Tabel 2. Perbedaan Peningkatan Kemampuan Psikomotor Ibu Bayi Antara yang Mendapat TKT dan Tidak Mendapatkan TKT

\begin{tabular}{lcc}
\hline \multicolumn{1}{c}{ Pengukuran } & Mean $(\boldsymbol{\%})$ & p \\
\hline Mendapatkan TKT & $20,70 \%$ & 0,000 \\
Tidak Mendapatkan TKT & $0,38 \%$ & $0,00 \%$ \\
\hline
\end{tabular}


Tabel 3. Perbedaan Peningkatan Kemampuan Bayi dan Perkembangan Rasa Percaya Bayi antara yang Mendapat TKT dan Tidak Mendapatkan TKT

\begin{tabular}{lcc}
\hline \multicolumn{1}{c}{ Pengukuran } & Mean(\%) & p \\
\hline Kemampuan Bayi & 12,82 & 0,000 \\
a. Mendapatkan TKT & 0,79 & \\
b. Tidak mendapatkan TKT & & \\
& & 0,000 \\
Rasa Percaya Bayi & 26,48 & \\
a. Mendapatkan TKT & 2,42 & \\
b. Tidak Mendapatkan TKT &
\end{tabular}

Tabel 4. Hubungan Kemampuan Ibu Bayi terhadap Kemampuan Bayi

\begin{tabular}{llccc}
\hline & Dependen & $\mathbf{R}$ & $\mathbf{R}^{2}$ & $\mathbf{p}$ \\
\hline Kemampuan Kognitif & Kemampuan Bayi & 0,733 & 0,537 & 0,000 \\
Kemampuan Psikomotor & Kemampuan Bayi & 0,904 & 0,871 & 0,000 \\
\hline
\end{tabular}

Tabel 5. Hubungan Kemampuan Ibu Bayi terhadap Rasa Percaya Bayi

\begin{tabular}{llccc}
\hline & Dependen & $\mathbf{R}$ & $\mathbf{R}^{2}$ & $\mathbf{p}$ \\
\hline Kemampuan Kognitif & Rasa Percaya Bayi & 0,801 & 0,642 & 0,000 \\
Kemampuan Psikomotor & Rasa Percaya Bayi & 0,722 & 0,522 & 0,000 \\
\hline
\end{tabular}

Tabel 6. Hubungan Kemampuan Bayi terhadap Rasa Percaya Bayi

\begin{tabular}{llccc}
\hline & Dependen & $\mathbf{R}$ & $\mathbf{R}^{\mathbf{2}}$ & $\mathbf{p}$ \\
\hline Kemampuan Bayi & Rasa Percaya Bayi & 0,768 & 0,590 & 0,014 \\
\hline
\end{tabular}

bulan dan berat badan waktu lahir memiliki bobot rata-rata sebesar $3,13 \mathrm{~kg}$ dengan berat badan waktu lahir terendah yakni $2,6 \mathrm{Kg}$ dan berat badan waktu lahir tertinggi $4 \mathrm{Kg}$.

Tabel 1 menunjukkan bahwa ada perbedaan peningkatan secara signifikanpada kemampuan kognitif ibu bayi sebesar $36,17 \%$ pada ibu yang mendapatkan TKT dan penurunan sebesar 3, $42 \%$ pada ibu yang tidak mendapatkan TKT. Pada Tabel 2 menunjukkan bahwa ada perbedaan peningkatan secara signifikan pada kemampuan psikomotor ibu bayi sebesar $20,70 \%$ pada ibu yang mendapatkan TKT dan peningkatan sebesar $0,38 \%$ pada ibu yang tidak mendapatkan TKT.

Tabel 3 menunjukkan bahwa ada perbedaan peningkatan secara signifikan pada kemampuan bayi sebesar $12,82 \%$ pada bayi yang mendapatkan TKT dan peningkatan sebesar $0,79 \%$ pada ibu yang tidak mendapat TKT. Sedangkan pada perkembangan rasa percaya bayi menunjukkan bahwa ada perbedaan peningkatan rasa percaya bayi secara signifikan pada bayi yang mendapatkan TKT sebesar $26,48 \%$ dan yang tidak mendapatkan TKT sebesar 2,42\%.

Tabel 4 menunjukkan bahwa ada hubungan kekuatan sedang untuk kemampuan kognitif ibu terhadap kemampuan bayi $(r=0,733)$. Sedangkan untuk kemampuan psikomotor ibu bayi menunjukkan bahwa terdapat hubungan dengan kekuatan tinggi antara kemampuan psikomotor ibu terhadap kemampuan bayi $(\mathrm{r}=0,904)$.

Tabel 5 menunjukkan bahwa terdapat hubungan dengan kekuatan sedang antara kemampuan 
kognitif ibu bayi terhadap rasa percaya bayi (r= 801). Sedangkan untuk kemampuan psikomotor ibu bayi menunjukkan terdapat hubungan dengan kekuatan sedang antara kemampuan psikomotor ibu terhadap rasa percaya bayi $(\mathrm{r}=$ $0,722)$.

Tabel 6 menunjukkan bahwa terdapat hubungan dengan kekuatan sedang antara kemampuan bayi terhadap rasa percaya bayi $(r=0,768)$.

\section{Pembahasan}

Hasil penelitian menunjukkan terdapat perbedaan peningkatan yang signifikan antara kemampuan kognitif ibu bayi yang mendapat TKT dan yang tidak mendapatkan TKT. Hal ini sejalan dengan penelitian yang dilakukan oleh Restiana, et al. (2010) yang menunjukkan kemampuan kognitif ibu bayi tentang konsep stimulasi bayi dapat meningkat setelah dilakukan TKT.

Hasil penelitian ini juga sejalan dengan penelitian yang dilakukan oleh Sunarto, Keliat dan Pujasari (2011) menunjukkan peningkatan pengetahuan, psikomotor dan perkembangan industri secara bermakna setelah di berikan terapi terapeutik. Kemudian penelitian ini didukung oleh penelitian yang dilakukan Trihadi (2009), menunjukkan Terapi Kelompok Terapeutik meningkatkan kemampuan kognitif ibu bayi dalam melakukan stimulasi perkembangan usia kanakkanak secara bermakna.

Perbedaan peningkatan yang signifikan antara yang mendapat TKT dan tidak mendapatkan TKT yang artinya terapi kelompok terapeutik dapat meningkatkan kemampuan ibu dalam menstimulasi perkembangan bayi tentang konsep stimulasi dan menunjukkan pentingnya melakukan terapi kelompok terapeutik untuk meningkatkan kemampuan ibu.

Hasil penelitian juga menunjukkan terdapat perbedaan peningkatan yang signifikan antara kemampuan psikomotor ibu yang mendapatkan TKT dan yang tidak mendapatkan TKT. Hal ini sesuai dengan penelitian Rogers (1974 dalam Notoatmodjo, 2012) mengungkapkan bahwa sebelum orang mengadopsi perilaku baru di dalam diri orang tersebut terjadi proses berurutan yaitu awareness, interest, evaluation, trial dan adoption. Oleh karena itu dibutuhkan adanya terapi yang dapat memberikan ibu pengetahuan tentang cara melakukan stimulasi yaitu terapi kelompok terapeutik.

Peningkatan kemampuan psikomotor bisa terjadi karena dalam terapi terjadi proses belajar yang dalam pelaksanaannya kelompok ibu mendapatkan latihan cara melakukan stimulasi selama 7 sesi yang dilakukan dalam 9 kali pertemuan. Melalui intervensi tersebut, kegiatan yang sebelumnya sudah pernah dilakukan oleh sebagian ibu diulang kembali sehingga diharapkan menjadi suatu kebiasaan, sedangkan untuk kelompok ibu yang belum pernah melakukan kegiatan stimulasi dini pada anaknya, diharapkan selama terapi ibu-ibu memperoleh pengetahuan baru yang akan menjadi dasar pembentukan keterampilan baru sehingga kemampuan ibu dalam melakukan stimulasi perkembangan psikososial pada bayi dapat meningkat.

Proses otomatisme dan proses adoption pada sebagian ibu bisa terjadi karena dalam pelaksanaan Terapi Kelompok Terapeutik pemberian informasi terkait kebutuhan perkembangan anak usia tersebut dilakukan dan dilanjutkan dengan memberikan contoh (demonstrasi) kepada keluarga tentang cara memberikan stimulasi perkembangan rasa percaya bayi dan memberikan kesempatan ibu untuk melakukan kembali (role play) cara memberikan stimulasi perkembangan pada anak. Pelaksanaan Terapi Kelompok Terapeutik pada ibu memengaruhi kemampuan psikomotor ibu dalam memberikan stimulasi perkembangan usia pra sekolah. Perilaku yang didasari pengetahuan akan mampu bertahan dalam waktu yang lebih lama.

Perbedaan peningkatan yang mendapat TKT dan tidak mendapat TKT berbeda secara signifikan yang artinya terapi kelompok terapeutik 
dapat meningkatkan kemampuan psikomotor dalam menstimulasi perkembangan bayi pada aspek motorik (Restiana, et al., 2010).

Hasil penelitian juga menunjukkan terdapat perbedaan yang signifikan antara kemampuan bayi yang mendapat TKT dan yang tidak mendapatkan TKT. Perbedaan secara bermakna ini disebabkan oleh adanya kegiatan dalam pelaksanaan terapi kelompok terapeutik yang berkaitan dengan peningkatan psikomotor ibu karena adanya demonstrasi dan latihan dalam melakukan stimulasi perkembangan. Demonstrasi dan latihan yang dilakukan ibu meliputi cara menstimulasi aspek motorik sehingga ibu dapat menstimulasi pada bayinya sesuai dengan yang dicontohkan kemudian ibu dapat melakukan latihan dan mempraktekannya sehingga stimulasi yang diberikan semakin sering maka kemampuan bayinya juga akan meningkat. Hal Ini sesuai dengan pemyataan Soetjiningsih dan Ranuh (2012) bahwa peningkatan perkembangan bayi dipengaruhi oleh faktor sosial yaitu stimulasi.

Perbedaan peningkatan yang mendapat TKT dan tidak mendapatkan TKT berbeda secara signifikan yang artinya terapi kelompok terapeutik dapat meningkatkan kemampuan bayi. Hasil penelitian juga menunjukkan terdapat perbedaan yang signifikan antara kelompok yang mendapat TKT dan yang tidak mendapat TKT. Peningkatan rasa percaya secara bermakna disebabkan oleh adanya kegiatan dalam pelaksanaan terapi kelompok terapeutik yang berkaitan dengan peningkatan pengetahuan ibu baik secara kognitif dan psikomotor sehingga dapat melatih bayinya yang pada akhirnya dapat meningkatkan kemampuan bayi dan rasa percaya bayi. Hal ini didukung teori stimulasi yang dikemukakan oleh Wong, HockenberryEaton, Wilson, Winkelstein, dan Schwartz (2008) yang menunjukkan bahwa keadaan percaya atau rasa percaya bayi mengandung tiga aspek yaitu pertama bayi belajar percaya pada keamanan dan kesinambungan dari pengasuh diluarnya, bayi belajar percaya diri dan dapat percaya kemampuan organ-organnya sendiri untuk menanggulangi dorongan-dorongan dan bayi menganggap dirinya cukup dapat dipercaya (Wong, et al., 2008; Santrock, 2007; Hurlock, 1991).

Kelompok ibu yang tidak TKT terdapat pula peningkatan skor rata-rata perkembangan rasa percaya bayi yaitu sebesar $0,78(2,42 \%)$ dari $66,88 \%$ menjadi $69,30 \%$. Peningkatan skor rata-rata perkembangan rasa percaya bayi yang terjadi pada kelompok ibu yang tidak mendapat terapi kelompok terapeutik tidak sebaik peningkatan perkembangan rasa percaya yang terjadi pada kelompok ibu yang mendapat terapi kelompok terapeutik. Pada aspek perkembangan terjadi peningkatan yang bermakna karena kemampuan perkembangan ini dapat meningkat selain dipengaruhi stimulasi juga dapat dipengaruhi oleh faktor lain. Menurut Soetjiningsih dan Ranuh (2012) faktor faktor yang memengaruhi tumbuh kembang adalah faktor genetik dan faktor lingkungan.

Perbedaan peningkatan rasa percaya bayi yang mendapatkan TKT dan tidak mendapat TKT berbeda secara signifikan yang artinya terapi kelompok terapeutik dapat meningkatkan rasa percaya bayi. Hasil penelitian menunjukkan ada hubungan dengan kekuatan sedang antara kemampuan kognitif ibu dengan kemampuan bayi $(\mathrm{r}=0,733)$ dan berpola positif artinya semakin bertambah kemampuan kognitif ibu maka semakin bertambah kemampuan bayinya. Kemampuan kognitif ibu dalam memberikan stimulasi perkembangan memengaruhi kemampuan bayi dan sisanya dipengaruhi oleh faktor lain.

Hal ini sejalan dengan penelitian yang dilakukan oleh Kurniawati dan Hanifah (2015) menunjukkan bahwa ada hubungan pengetahuan ibu terhadap stimulasi tumbuh kembang balita usia 12-36 bulan. Penelitian ini didukung juga oleh penelitian Nurhasanah dan Ismawati (2015) menunjukkan bahwa terdapat hubungan yang signifikan antara tingkat pengetahuan ibu dengan stimulasi perkembangan motorik anak usia 1-3 tahun. 
Hasil penelitian menunjukkan ada hubungan dengan kekuatan hubungan tinggi antara kemampuan psikomotor ibu dengan kemampuan bayi $(r=0,904)$ dan berpola positif artinya semakin bertambah kemampuan psikomotor ibu maka semakin bertambah kemampuan bayinya. Kemampuan psikomotor ibu dalam memberikan stimulasi perkembangan memengaruhi kemampuan bayi dan sisanya dipengaruhi oleh faktor lain.

Hasil penelitian ini didukung oleh penelitian Hasanah dan Ansori (2013), hasilnya menunjukkan terdapat hubungan antara tingkat pengetahuan ibu dengan perkembangan motorik kasar di PAUD. Penelitian oleh Setyaningsih, Nurhidhariani, dan Putri (2016) menunjukkan ada hubungan antara pengetahuan ibu dengan perkembangan motorik kasar anak.

Hasil penelitian lainnya menunjukkan ada hubungan dengan kekuatan sedang antara kemampuan kognitif ibu dalam memberikan stimulasi perkembangan dini pada bayi dengan perkembangan bayi $(r=0,801)$ dan berpola positif artinya semakin bertambah kemampuan kognitif ibu dalam memberikan stimulasi perkembangan semakin bertambah perkembangan bayi. Hubungan ini menerangkan bahwa sebesar 64,2\% kemampuan kognitif ibu dalam memberikan stimulasi perkembangan memengaruhi perkembangan rasa percaya dan sisanya dipengaruhi oleh faktor lain.

Hasil penelitian ini sesuai dengan pendapat Soetjiningsih dan Ranuh (2012) yang mengatakan bahwa faktor yang memengaruhi tumbuh kembang adalah pengetahuan ibu. Hasil penelitian juga menunjukkan ada hubungan dengan kekuatan sedang antara kemampuan psikomotor dengan rasa percaya bayi $(r=0,722)$ dan berpola positif artinya semakin bertambah kemampuan psikomotor ibu dalam memberikan stimulasi perkembangan semakin bertambah perkembangan rasa percaya bayi.

Kemampuan psikomotor ibu dalam memberi stimulasi perkembangan memengaruhi perkem- bangan rasa percaya bayi sebesar $52,2 \%$ dan sisanya dipengaruhi oleh faktor lain. Hal ini sesuai pernyataan Soetjiningsih dan Ranuh (2012) bahwa perkembangan bayi dipengaruhi oleh kemampuan keluarga dalam memberikan stimulasi. Bayi yang mendapat stimulasi yang terarah akan lebih cepat berkembang dibandingkan bayi yang kurang atau bahkan tidak mendapat stimulasi dan stimulasi dapat meningkatkan perkembangan bayi dalam perkembangan kognitif, perkembangan afektif, perkembangan motorik (Kania, 2007; Baraja, 2008).

Hal ini juga didukung oleh Arifah, Rahmawati, dan Dewi (2013) bahwa peran ibu sangat penting sekali dalam pemenuhan kebutuhan dasar anak terutama pada bayinya. Peranan ibu dalam pemenuhan kebutuhan dasar bayinya dikelompokkan menjadi tiga yaitu kebutuhan asih yaitu pemenuhan kebutuhan fisik, asuh yaitu pemenuhan kebutuhan emosi atau kasih sayang dan asah sebagai pemenuhan stimulasi yaitu pemberi stimulasi bagi perkembangan bayi, perkembangan dari organ-organ ini sangat ditentukan oleh rangsang yang diterima bayi dan ibunya dan rangsangan yang diberikan oleh ibu, akan memperkaya pengalaman dan mempunyai pengaruh yang besar bagi perkembangaa kognitif bayi. Oleh karena itu, seorang ibu harus mempunyai kemampuan psikomotor tentang cara memberikan stimulasi perkembangan pada bayinya.

Dalam terapi kelompok terapeutik terapi ini ada demonstrasi dan latihan sehingga ibu dapat mempraktekannya di rumah, sehingga setelah dilakukan terapi kelompok terapeutik ada hubungan antara psikomotor dengan perkembangan bayi. Dengan pemberian stimulasi ke delapan aspek yang meliputi aspek motorik, kognitif, bahasa, emosional, kepribadian, moral, spiritual dan bahasa dapat meningkatkan rasa percaya bayi karena bayi akan percaya jika diberikan rasa nyaman, diberikan pujian, dipeluk dan diajak bicara oleh ibunya.

Terapi kelompok terapeutik adalah merupakan salah satu jenis terapi dari terapi kelompok 
memberikan kesempatan kepada orang lain, untuk menemukan caradalam menyelesaikan masalah dan mengatasi masalah dengan mengajarkan secara efektif dan efesien sehingga dapat meningkatkan kemampuan (Townsend, 2009). Tindakan yang dilakukan secara berulang-ulang akan meningkatkan pada kemampuan anak, terutama masa bayi karena dalam masapercaya ini masa bayi adalah masa yang sangat kritis, karena disini masalah rasa kepercayaan atau sering disebut dengan Trust, Erikson (1963) sering mengatakan bahwamasa ini di disebut dengan masa Growth and Crisis of the Healthy Personality yang menunjukkan rasa percaya yang didapat dalam tahun pertama.

Hasil penelitian lainnya menunjukkan ada hubungan dengan kekuatan sedang antara kemampuan psikomotor ibu bayi dengan rasa percaya bayi $(r=0,768)$ dan berpola positif artinya semakin bertambah kemampuan bayi dalam memberikan stimulasi perkembangan semakin bertambah perkembangan rasa percaya bayi. $\mathrm{Hu}-$ bungan ini menunjukkan sebesar 59,0\% kemampuan bayi memengaruhi rasa percaya bayi dan sisanya dipengaruhi oleh faktor lain.

Peningkatan rasa percaya secara bermakna ini kemungkinan disebabkan oleh adanya kegiatan dalam pelaksanaan terapi kelompok terapeutik yang berkaitan dengan peningkatan pengetahuan ibu baik secara kognitif dan psikomotor sehingga dapat melatih bayinya yang pada akhirnya dapat meningkatkan kemampuan bayi dan rasa percaya bayi.

\section{Kesimpulan}

Karakteristik ibu yang mempunyai bayi dengan usia termuda 17 tahun dan tertua 43 tahun dan rata-rata usia keluarga dalam penelitian ini antara 28,94 tahun. Karakteristik usia bayi paling muda 6 bulan dan tertua 11 bulan dengan rata rata usia bayi dalam penelitian ini antara 7,32 bulan sampai dengan 9,9 bulan. Perbedaan peningkatan yang signifikan pada kemampuan kognitif ibu bayi, kemampuan psikomotor ibu bayi, kemampuan bayi dan rasa percaya bayi pada ibu yang mendapatkan TKT dan tidak mendapatkan TKT.

Kemampuan kognitif ibu bayi memiliki hubungan dengan kekuatan sedang dengan kemampuan dan rasa percaya bayi. Kemampuan psikomotor ibu memiliki hubungan dengan kekuatan tinggi dengan kemampuan bayi dan memiliki hubungan dengan kekuatan sedang dengan rasa percaya bayi. Kemampuan bayi memiliki hubungan dengan kekuatan sedang dengan rasa percaya bayi.

Penelitian ini diharapkan sebagai masukan bagi Dinas Kesehatan Kabupaten Bone Bolango, Puskesmas, Kader, Organisasi Profesi agar bekerjasama untuk meningkatkan upaya kesehatan ibu dan anak dan gizi keluarga dalam kegiatan posyandu pada kelompok sehat yang berbasis komunitas sesuai dengan isu kesehatan jiwa di dunia yaitu pemberdayaan masyarakat (LL, YA, TN).

\section{Referensi}

Arifah, N., Rahmawati, I., \& Dewi, E.I. (2013). Hubungan pemenuhan kebutuhan dasar balita (asuh, asah, dan asih) dengan perkembangan balita yang berstatus BGM (bawah garis merah) di Desa Sukojember Kecamatan Jelbuk Kabupaten Jember. Jurnal IKESMA, 9 (2), 97-105.

Baraja, A. (2007). Psikologi perkembangan tahapan dan aspek-aspeknya dari 0 tahun sampai akil balik. Jakarta: Studia Press.

Depkes RI. (2006). Stimulasi, deteksi, dan intervensi rasa percaya tumbuh kembang anak di tingkat pelayanankesehatan dasar. Jakarta: Departemen Kesehatan RI. Diperoleh dari http://depkes.go.id.

Erikson, E.H. (1963). Childhood and society (2nd Ed.). New York: W.W. Norton and Company.

Furniss, T., Müller, J.M., Achtergarde, S., Wessing, I., Averbeck-Holocher, M., \& Postert, C. 
(2013). Implementing psychiatric day treatment for infants, toddlers, preschoolers and their families: A study from a clinical and organizational perspective. International Journal of Mental Health Systems, 7 (1) 112. doi: 10.1186/1752-4458-7-12.

Hasanah, N., \& Ansori, M.N. (2013). Hubungan tingkat pengetahuan ibu dengan perkembangan Motorik kasar anak usia (3-5 tahun). Jurnal Midpro, 2, 60-66. Diperoleh dari http://journal.unisla.ac.id/

Hurlock, E.B. (1991). Developmental psychology: A life span approach (5th Ed.). Jakarta: Erlangga.

Kania, N. (2007). Stimulasi dini untuk mengembangkan kecerdasan dan kreativitas anak. Bandung: Universitas Padjajaran. Diperoleh dari http://repository.unpad.ac.id/4569/.

Komisi Perlindungan Anak Indonesia. (2013). Laporan kasus kekerasan terhadap anak. Jakarta: Komisi Perlindungan Anak RI.

Kurniawati, A., \& Hanifah, L. (2015). Hubungan pengetahuan ibu tentang stimulasi tumbuh kembang balita dengan perkembangan balita usia 12-36 bulan di posyandu kasih ibu 7 Banyu Urip Klego Boyolali tahun 2014. Jurnal Kebidanan Indonesia, 6 (1), 83-100. Diperoleh dari http://jurnal.stikesmus.ac.id/

Notoatmodjo, S. (2012). Promosi kesehatan dan ilmu perilaku. Jakarta: Reneka Cipta.

Nurhasanah, N., \& Ismawati, I. (2015). Hubungan tingkat pengetahuan ibu tentang stimulasi dengan per ke mbangan motorik anak usia 13 tahun di Posyandu Teratai I Desa Bangunjiwo tahun 2015 (Skripsi, tidak dipublikasikan). Yogyakarta: Program Studi Bidan Pendidik Jenjang D IV Sekolah Tinggi Ilmu Kesehatan 'Aisyiyah. Diperoleh dari http://digilib.unisayogya.ac.id/113/1/Naskah $\% 20$ Publikasi\%20Nurhasanah.pdf.

Putri, I. (2008). Hukuman di dalam pendidikan studi kasus di SMKN 1 Padang (Skripsi, tidak dipublikasikan). Fakultas Ilmu Sosial dan Ilmu Politik Univeristas Andalas, Padang.
Restiana, N., Keliat, B.A., Gayatri, D. \& Daulima, N.H.C. (2010). Pengaruh terapi kelompok terapeutik terhadap kemampuan ibu dalam menstimulasi rasa percaya bayi di Kelurahan Mulyasari Kota Tasikmalaya (Tesis, tidak dipublikasikan). Fakultas Ilmu Keperawatan Universitas Indonesia, Depok.

Santrock, J.W. (2007). Child development (11th Ed.). Boston: Mcgraw-Hill.

Setyaningsih, A., Nurhidhariani, R., \& Putri, A.A. (2016). Hubungan tingkat pengetahuan ibu dan praktek penggunaan alat permainan edukatif dengan perkembangan motorik kasar di PAUD Anggrek Kabupaten Pati. Jurnal Smart Keperawatan, 3 (1), 1-9. Diperoleh dari http://stikesyahoedsmg.ac.id/ jurnal/?p=1.

Smith, J.C., Cumming, A., \& Xeros-Constantinides, S. (2010). A decade of parent and infant relationship support group therapy programs. Int J Group Psychother, 60 (1), 59-89. doi: 10.1521/ijgp.2010.60.1.59..

Soetjiningsih, S., \& Ranuh, I.G.N.G. (2012). Tumbuh kembang anak (Edisi 2). Jakarta: EGC.

Sunarto, M., Keliat, B.A., \& Pujasari, H. (2011). Pengaruh terapi kelompok terapeutik anak sekolah pada anak, orangtua, guru terhadap perkembangan mental anak di Kelurahan Pancoranmas dan Depok Jaya (Tesis, tidak dipublikasi). Fakultas Ilmu Keperawatan Universitas Indonesia, Depok.

Townsend, C.M. (2009). Essentials of psychiatric mental, health nursing. Philadelphia: F.A. Davis Company.

Trihadi, D. (2009). Pengaruh terapi kelompok terapeutik terhadap kemampuan keluarga dalam memberikan stimulasi perkembangan dini pada usia 1,5-3 tahun di Kelurahan Bubulak Kota Bogor Tahun 2009 (Tesis, tidak dipublikasikan). Fakultas Ilmu Keperawatan Universitas Indonesia, Depok.

Videbeck, S.L. (2008). Buku ajar keperawatan jiwa. Jakarta: EGC. 
WHO. (2003). Mental health legislation and human rights. Geneva: WHO.

Wong, D.L., Hockenberry-Eaton, M., Wilson, D., Winkelstein, M.L., \& Schwartz, P. (2008). Buku ajar keperawatan pediatrik (Edisi 6). Jakarta: EGC. 